\title{
Anti-Diabetic Activity of Some Medicinal Plants
}

\author{
Qurat-ul-ain ${ }^{1}$, Muhammad Asif Raheem ${ }^{1}$, Muhammad Saeed ${ }^{1} \&$ Dr. Tahir Yasin ${ }^{2}$ \\ ${ }^{I}$ Centre of Agricultural Biochemistry and Biotechnology (CABB), University of Agriculture Faisalabad (UAF), Pakistan. \\ ${ }^{2}$ Postgraduate Resident MD Cardiology, CPE Institute of Cardiology, Multan, Pakistan.
}

Copyright: () 2021 Qurat-ul-ain et al. This is an open access article distributed under the terms of the Creative Commons Attribution License, which permits unrestricted use, distribution, and reproduction in any medium, provided the original author and source are credited.

\section{ABSTRACT}

Diabetes mellitus is generally a chronic disease which is a main reason for deaths in whole world. It is not easy to control the delayed complication of diabetes even with progress in the medical management of the syndrome. The disease is spreading day by day. The main trait element of diabetes is hyperglycemia, which reflects the drop in the use of glucose due to a poor reaction to insulin discharge. There are many plants are used to cure diabetes because of the antidiabetic action. Hypoglycemic and anti-hyperglycemic actions have been saved with abundant plants, a lot of which are worn as an established herbal treatment of diabetes. A huge number of substances are obtained from plants that suggest antidiabetic potential, while others may affect hypoglycemia as a bad result due to their toxicity, mainly their hepatotoxicity. This review shows the importance of plants and the action of some plants to act against diabetes that is used as a natural medicine for this disease.

Keywords: Diabetes mellitus, Medicinal plants, Hyperglycemic, Antioxidant.

\section{Introduction}

From the creation of humans, they were probably affected with diseases and with the passage of time started to use a variety of ingredients together with flora, animals, insects, or natural resources to cure different diseases. It was expected that the population was aware of the importance of plants as medicine from thousands of years ago. Plants are used for naturally improving health. Plants are not only used for the treatment of diseases but also for improving life in different ways as improving income and making an enjoyable lifestyle. Today diseases are spreading. Diabetes is a commonly present syndrome that is rising at a frightening speed and has become one of the world's most severe public health troubles. It is a disease of endocrine structure that is carbohydrate metabolism disease due to a whole or relative insufficiency of insulin discharge, achievement, or together. Diabetes mellitus is affecting millions of people all over the world and many people affected by it. It has become a challenge to control this increasing number. It has become more problematic for health and even it because of the death of millions of people in developed countries and is a threat in many rising and recently industrialized countries. In different countries the ratio of causing death is different. Diabetes will be the seventh top source of death in 2030, according to the World Health Organization (WHO) ${ }^{1}$.

Diabetes mellitus is divided into three main categories: Type 1 that depends on insulin, type 2 that does not depend on insulin or is insulin-free and the third and last kind is gestational diabetes. Type 1 diabetes is a syndrome that causes the damage of pancreatic $\beta$-cells which respond in opposition to endogenous antigen. It is present in about $5 \%-10 \%$ of patients with diabetes and is mostly seen in people above the age of 20 years. Second type 2 Diabetes. Of all three types, Type 2 Diabetes is the most common and highly affecting type. Almost $90 \%-95 \%$ of people are suffering from this type of diabetes. Different studies show the well-built hereditary foundation for the progress of $2^{\text {nd }}$ type diabetes. The occurrence is because of a disorder in insulin work in addition to discharge. The most common type equally in the worldwide and Indian state is the kind 2 or else insulin-independent diabetes mellitus 
which is linked with important postprandial hyperglycemia. The principal to the increase of type 2 Diabetes has not been completely confirmed, but it is identified that there are hazardous causes for raising the disease such same as fatness, later age, an inactive way of life, and reduced intake behavior ${ }^{2}$.

Both types of the disease show different characters and cause different complications. Different factors are the source of diabetes some are ecological factors; fatness, as well as later age, are some of them. Sometimes due to less action of insulin on the different target tissue, there is an insufficiency or extra concentration of proteins, carbohydrates, and lipids and at more time hyperglycemia causes the loss of vision and nephropathy which are the main symptoms of Diabetes. It also causes heart disease, a cardiovascular syndrome ${ }^{2}$.

Even though the more advanced improvements in the medical field, plants are still used as medicine to cure different disorders. To Cure Diabetes, a huge quantity of plants is used as medicine due to their antidiabetic activity. Natural antioxidants perform a role to combat oxidative stress and prevent many diseases including diabetes. Vegetables along with the various plants' extracts are trying to use for the treatment of diabetes. The poor countries could not afford medical care and drugs that are more expensive, there the drugs obtained from plants are used for treatment that is cheaper medicine. Despite the synthesis of drugs with insulin for controlling diabetes, it is significant to use plants as medicines. Plants show antidiabetic activity and naturally cure diabetes disease at a small cost. Plants show hypoglycemic function ${ }^{3}$.

\section{Plants Used as Medicines Due to their Antidiabetic Activity}

In this review, some plants are collected from different articles that are used as medicines due to their antidiabetic activity. The study shows the helpfulness of the plants in the management of diabetes mellitus. Different plants were used as antidiabetic in early times and nowadays and their activity as medicinal plants to cure diabetes is discussed.

\section{a) Lactuca sativa}

As Persian medicine to cure diabetes the kernel has been using that is called "Khas" from recent times. It contains the action to inhibit enzymes $\alpha$-glycosidase and $\alpha$-amylase. Grains in a polyherbal method verified anti-diabetic achievement from first to end obtaining insulin by decreasing the concentration of enzymes that are the main basis of diabetes and enhancement of pancreatic tissue ${ }^{4}$.

\section{b) Portulaca oleracea}

Portulaca oleracea is a seed that acts as an antidiabetic agent. The powder obtained from the seed increases the glucagon level in type 2 diabetes similar to the intensity of peptide 1 . If these seeds are used in insulin-dependent diabetes patients it results from the enhancement of insulin fight and liver role, enhances, or decreases the concentration of lipoprotein cholesterol, changing total cholesterol level, lessening of fast, etc. The outer portion of plants shows the hypoglycemic activity as progressing the secretion of insulin and renewal of diabetic endothelial improper function through by making different changes. The leaves exhibited an anti-diabetic role by the establishment of antioxidant enzymes and by controlling the intensity of lipid for rust in the liver and kidney of the diabetic natural world ${ }^{5}$. 


\section{c) Azadirachta indica}

Azadirachta indica is prominent in India and its nearby countries commonly used health plants due to its broad range of natural action. Each part of this plant acts as a medicine and is also used for economic purposes. Azadirachta indicia is also famous due to its important properties such as an anti-microbe, anti-stirring, different pharmacological, and Antidiabetic. This plant reduces the intensity of glucose in the blood and reduces the absorption of an enzyme that acts as an antioxidant. Last research showed that the use of this plant in rats considerably improved the actions of antioxidants in hepatic structures signifying that leaf extract this plant has both antioxidant and antidiabetic capacity. It showed the declining level of hepatic glucagon in the rats that are fed with a rich amount of fat. Constant dealing with ethanol taken out of A. Indica has been revealed to lessen and improve the injured area of the liver in streptozotocin-induced rats having diabetes ${ }^{6}$.

\section{d) Ficus hispid}

Fruits of Ficus hispid plants were used to cure diabetes disease. Bark cut out of this plant has been exposed to show hypoglycemic action in diabetic and normal rats that have no diabetes ${ }^{7}$.

\section{e) Sonchus oleraceus}

Antioxidant action of Sonchus oleraceus plant was examined using the whole plant of S. oleraceus. The Antidiabetic activity was shown by this plant extract. The measurement of different factors such as stress markers in different parts of bodies, examination shows a high level of antioxidant. The different effects such as hypoglycemic action, in diabetic rats the capacity to avoid oxidative stress, etc. Chemical compounds present show that the compound obtained from the plant has a high intensity of the compounds that have an anti-diabetic capacity such as secondary metabolites and polyphenol content ${ }^{8}$.

\section{f) Vitis vinifera}

Huge sections of Vitis vinifera plant have been used to cure the different diseases of the beginning. The fruits of these plants that have not ripened were used as medicine in different places. These unripe fruits also have the anti-diabetic activity for which these are used by diabetic patients. It is based on conventional Persian meditation writing. The extract from seeds has defensive action from guts filament beside diabetic marginal neuropathy in insulin-independent mice. In other organisms containing another type of diabetes, it plays an important role in improving different functions for acting against diabetes. A medical test on insulin-independent patients shows that polyphenol taken out of fruits confirmed the increase of insulin understanding key and decline of glucose mixture speed, which show withdrawing the cellular insulin acceptance and inhibition of diabetic oxidative pressure. It was seen that the placebo group has more good effects on diabetic patients as compared to the serum or antioxidants obtained from seeds?

\section{g) Boswellia carterii}

The species of Boswellia has a dehydrated and warm character and is known as "Kandor" It is used to cure gastrointestinal troubles and other than for the inflammation treatment in medicinal books in Persia. An 
oleo-gum-resin of this plant has been used to cure diabetes. As it enhances the insulin level, glycogen in the liver and suppresses different changes in $\beta$ cells in the pancreas. It controls diabetes by reducing the apoptosis of peri-insular cell ${ }^{10}$.

\section{h) Moringa oleifera}

The material obtained from Moringa oleifera plant when used for 21 days reduces the increase of diabetes disease. Reduction in glucose and nitric oxide concentration was examined when both doses of MOMtE were applied to rats. The use of MOMtE to cure diabetes was to overturn structural injury in islet cells ${ }^{11}$.

\section{i) Coriandrum sativum}

Coriandrum sativum herb belongs to such plants which are important due to its use as eatables and to cure diseases. The dried outer portion newly originated parts, and fragrant fruits have been used in cooking and as indications for beneficial purposes. It has icy and dehydrated properties and has been used to cure a diverse quantity of diseases. To cure diabetes this plant has hyperglycemic action by increasing the glucose release. In some organisms having diabetes, this plant shows different changes that make able the organism suppress diabetes ${ }^{12}$.

Table 1. Mode of action of different plants

\begin{tabular}{|c|c|c|c|c|}
\hline $\begin{array}{c}\text { Botanical } \\
\text { Name }\end{array}$ & $\begin{array}{c}\text { Plant Part } \\
\text { Used }\end{array}$ & Extract used & Mode of action & Ref. \\
\hline $\begin{array}{c}\text { Lactuca } \\
\text { sativa }\end{array}$ & & & $\begin{array}{l}\text { Inhibit enzymes } \alpha \text {-glycosidase and } \alpha \text {-amylase. } \\
\text { Antidiabetic by obtaining insulin or decreasing } \\
\text { concentration of diabetes causing enzyme. } \\
\text { Enhancement of pancreatic tissues. }\end{array}$ & [4] \\
\hline $\begin{array}{c}\text { Portulaca } \\
\text { oleracea }\end{array}$ & $\begin{array}{c}\text { Seed } \\
\text { Outer portion } \\
\text { Leaves }\end{array}$ & Powder from seed & $\begin{array}{l}\text { Powder increase glycogen level in type } 2 \\
\text { diabetes patient. } \\
\text { More insulin fight, liver role, less lipoprotein } \\
\text { quantity cholesterol, total cholesterol level } \\
\text { change, etc. } \\
\text { Hyperglycemic action. } \\
\text { As antidiabetic by increasing antioxidant, lipid. }\end{array}$ & [5] \\
\hline $\begin{array}{c}\text { Azadirachta } \\
\text { indica }\end{array}$ & $\begin{array}{c}\text { Each part of } \\
\text { the plant }\end{array}$ & $\begin{array}{c}\text { Leaf extract } \\
\text { Ethanol }\end{array}$ & $\begin{array}{l}\text { Antimicrobe. } \\
\text { Anti-stirring. } \\
\text { Pharmacological. } \\
\text { Antidiabetic. } \\
\text { Less glucose in blood and enzyme that act as } \\
\text { antioxidant. } \\
\text { Lesson and improve injured area of the liver in } \\
\text { diabetic rats. }\end{array}$ & [6] \\
\hline
\end{tabular}




\begin{tabular}{|c|c|c|c|c|}
\hline Ficus hispid & $\begin{array}{l}\text { Fruit } \\
\text { Bark }\end{array}$ & & $\begin{array}{l}\text { Antidiabetic activity. } \\
\text { Hyperglycemic activity in normal and diabetic } \\
\text { rats. }\end{array}$ & [7] \\
\hline $\begin{array}{l}\text { Sonchus } \\
\text { oleraceus }\end{array}$ & Whole plant & $\begin{array}{c}\text { Chemical } \\
\text { obtained } \\
\text { secondary e.g., } \\
\text { metabolites, } \\
\text { polyphenol } \\
\text { content }\end{array}$ & $\begin{array}{l}\text { Antioxidant } \\
\text { Antidiabetic }\end{array}$ & [8] \\
\hline Vitis vinifera & $\begin{array}{l}\text { Unripened } \\
\text { fruit }\end{array}$ & $\begin{array}{l}\text { Seed extract } \\
\text { Phenol extract of } \\
\text { fruits }\end{array}$ & $\begin{array}{l}\text { For different many diseases including diabetes. } \\
\text { A defensive effect from guts filament beside } \\
\text { diabetic marginal neuropathy in } \\
\text { insulin-independent mice. } \\
\text { Confirmed more insulin accepting the key, low } \\
\text { glucose mixture speed resulting in less insulin } \\
\text { acceptance, inhibition of diabetic oxidative } \\
\text { pressure. }\end{array}$ & [9] \\
\hline $\begin{array}{c}\text { Boswellia } \\
\text { carterii }\end{array}$ & $\begin{array}{c}\text { Different } \\
\text { parts }\end{array}$ & Oleo-gum-resin & $\begin{array}{l}\text { Gastrointestinal problems. } \\
\text { Inflammation treatment. } \\
\text { Diabetes treatment (more insulin level, } \\
\text { glycogen in the liver and suppresses different } \\
\text { changes in } \beta \text { cells in the pancreas). }\end{array}$ & [10] \\
\hline $\begin{array}{l}\text { Moringa } \\
\text { oleifera }\end{array}$ & & $\begin{array}{l}\text { Different } \\
\text { materials } \\
\text { MOMtE }\end{array}$ & $\begin{array}{l}\text { Use } 21 \text { days suppresses diabetes. } \\
\text { Cure diabetes. }\end{array}$ & [11] \\
\hline $\begin{array}{l}\text { Coriandrum } \\
\text { sativum }\end{array}$ & $\begin{array}{l}\text { Different } \\
\text { parts or } \\
\text { whole as } \\
\text { different } \\
\text { diseases } \\
\text { treatment }\end{array}$ & $\begin{array}{l}\text { dried outer portion } \\
\text { newly originated } \\
\text { parts and fragrant } \\
\text { fruits }\end{array}$ & $\begin{array}{l}\text { Cooking, indications for beneficial purposes. } \\
\text { Antidiabetic. }\end{array}$ & [12] \\
\hline
\end{tabular}

\section{Conclusion}

Plants have been used to cure a huge number of diseases due to low cost and easy to use. People make much use of the plants because they are easily available and cure disease in a natural way. Diabetes is the mainly present syndrome that has become the more challenging disease and the spreading rate is increasing day by day. Lactuca 
sativa, Portulacaoleracea, Azadirachtaindica, Ficus hispid, Sonchusoleraceus, Vitisvinifera, Boswelliacarterii, Moringaoleifera, and Coriandrumsativumare some of the plants that are used to cure diabetes that is caused due to a high altitude of glucose. Plants show hyperglycemic and antioxidant activity due to which suppress the high intensity of glucose and cause the suppression of disease.

\section{Declarations}

\section{Source of Funding}

This research did not receive any grant from funding agencies in the public, commercial, or not-for-profit sectors.

\section{Competing Interests Statement}

The authors declare no competing financial, professional and personal interests.

\section{Consent for publication}

Authors declare that they consented for the publication of this research work.

\section{References}

[1] Bommer, C., Sagalova, V., Heesemann, E., Manne-Goehler, J., Atun, R., Bärnighausen, T., \& Vollmer, S., (2018). Global economic burden of diabetes in adults: projections from 2015 to 2030. Diabetes Care, 41(5): 963-970.

[2] Eisenbarth, G. S., (1986). Type I diabetes mellitus. New England journal of medicine, 314(21): 1360-1368.

[3] Patel, D.K., Kumar, R., Laloo, D., \& Hemalatha, S., (2012). Diabetes mellitus: an overview on its pharmacological aspects and reported medicinal plants having antidiabetic activity. Asian Pacific Journal of Tropical Biomedicine, 2(5): 411-420.

[4] Garg, M., Garg, C., Mukherjee, P. K., \& Suresh, B., (2004). Antioxidant potential of Lactuca sativa. Ancient science of life, 24(1): 6 .

[5] El-Sayed, M.I.K., (2011). Effects of Portulaca oleracea L. seeds in treatment of type-2 diabetes mellitus patients as adjunctive and alternative therapy. Journal of ethnopharmacology, 137(1): 643-651.

[6] Biswas, K., Chattopadhyay, I., Banerjee, R. K., \& Bandyopadhyay, U., (2002). Biological activities and medicinal properties of neem (Azadirachta indica), Current Science, 1336-1345.

[7] Cheng, J. X., Zhang, B. D., Zhu, W. F., Zhang, C. F., Qin, Y. M., Abe, M., \& Zhang, J., (2020). Traditional uses, phytochemistry, and pharmacology of Ficus hispida Lf: A review. Journal of ethnopharmacology, 248, 112204.

[8] Teugwa, C. M., Mejiato, P. C., Zofou, D., Tchinda, B. T., \& Boyom, F. F., (2013). Antioxidant and antidiabetic profiles of two African medicinal plants: Picralima nitida (Apocynaceae) and Sonchus oleraceus (Asteraceae). BMC complementary and alternative medicine, 13(1): 1-9.

[9] Newman, K. L., Almeida, R. P., Purcell, A. H., \& Lindow, S. E., (2003). Use of a green fluorescent strain for analysis of Xylella fastidiosa colonization of Vitis vinifera. Applied and Environmental Microbiology, 69(12): $7319-7327$. 
Asian Journal of Basic Science \& Research Volume 3, Issue 4, Pages 15-21, October-December 2021

[10] Moussaieff, A., \& Mechoulam, R., (2009). Boswellia resin: from religious ceremonies to medical uses; a review of in-vitro, in-vivo and clinical trials. Journal of Pharmacy and Pharmacology, 61(10): 1281-1293.

[11] Anwar, F., Latif, S., Ashraf, M., \& Gilani, A. H., (2007). Moringa oleifera: a food plant with multiple medicinal uses. Phytotherapy Research: An International Journal Devoted to Pharmacological and Toxicological Evaluation of Natural Product Derivatives, 21(1): 17-25.

[12] Pandey, S., (2010). Coriandrum sativum: a biological description and its uses in the treatment of various diseases. International Journal of Pharmacy and Life Sciences, 1(3): 119-126. 